\title{
Field evaluation of the entomopathogenic nematodes against the white grub, Leucopholis lepidophora Blanchard (Coleoptera: Scarabaeidae)
}

\author{
Jagadeesh Patil ${ }^{*}$ and Vijayakumar Rangasamy
}

\begin{abstract}
The ability of entomopathogenic nematodes to suppress larval populations of the white grub, Leucopholis lepidophora Blanchard (Coleoptera: Scarabaeidae), infesting the areca nut palm (Areca catechu) was investigated under field conditions over a 2-year period (2015-2017). Heterorhabditis indica at two application rates $\left(1.7 \times 10^{5}\right.$ and $\left.3.5 \times 10^{5} \mathrm{IJs}_{\text {s }} \mathrm{slm}^{-1}\right)$ caused higher percentage reduction of L. lepidophora larvae than Steinernema abbasi and chlorpyrifos. Chlorpyrifos-treated plots caused higher percentage of reduction of the grub larvae than $\mathrm{S}$. abbasi at the lowest rate $\left(1.7 \times 10^{5} \mathrm{IJs}\right.$ palm $\left.\mathrm{m}^{-1}\right)$. However, S. abbasi at $3.5 \times 10^{5} \mathrm{IJs}$ palm ${ }^{-1}$ performed at least equally well than the chlorpyrifos treatment. The kernel yield from $H$. indica-treated plots at $3.5 \times 10^{5} \mathrm{IJ} \mathrm{palm^{-1 }}$ was $85.4 \%$ higher than those from water control and $33.3 \%$ higher than that in the chlorpyrifos treatment. The kernel yields varied significantly among different treatments. The cost-benefit analysis showed that $\mathrm{H}$. indica is a promising biocontrol agent for the management $\mathrm{L}$. lepidophora control in areca nut field.
\end{abstract}

Keywords: Areca nut, Leucopholis lepidophora, Biocontrol, Entomopathogenic nematodes

\section{Background}

Root injury caused by the larvae of the white grub, Leucopholis lepidophora Blanchard (Coleoptera: Scarabaeidae), threatens the production of areca nut palm or betel nut palm L. (Areca catechu) in the Western Ghats, Eastern Ghats and East and North Eastern regions of India. L. lepidophora is a basically dominant white grub species in high rainfall and Western Ghats regions of India and is widely regarded as the most serious threat to areca nut production in India (Veeresh 1983), causing yield losses up to 39.8-41. 6\% (Kalleshwaraswamy et al. 2015). L. lepidophora is also a key pest-causing damage to sugarcane, rice, maize (Adsule and Patil 1994), and peanuts (Ranga Rao and Rameshwar Rao 2013),

Since the white grub larvae are subterranean, the damage prediction is difficult and their management has always been problematic. The control of white grub larvae in India mainly depends on application of chemical

\footnotetext{
* Correspondence: patiljaggi@gmail.com

Division of germplasm collection and characterization, ICAR-National Bureau of Agricultural Insect Resources, P. B. No. 2491, H. A. Farm Post, Bellary Road, Bengaluru 560 024, India
}

insecticides. However, the control efficacy was not satisfactory because of quick development of insecticide resistance. With more concerns for the environment and human safety, environmentally friendly control strategies for L. lepidophora control are urgently needed to replace the highly toxic chemical pesticides.

Entomopathogenic nematodes (EPNs) from the families Steinernematidae and Heterorhabditidae are potential alternatives for the control of soil-dwelling pests (Toepfer et al. 2010), because of their ability to actively search for their hosts (Kaya and Gaugler 1993; Grewal et al. 2005; Georgis et al. 2006 and Yan et al. 2012). Previous studies have shown that EPN species such as Steinernema scarabaei Stock and Koppenhofer, S. longicaudum Shen and Wang, S. lanmjungense Khatri-Chhetri, Heterorhabditis bacteriophora Poinar, H. zealandica Poinar and H. indica Poinar (Koppenhofer et al. 2000; Koppenhofer and Fuzy 2003; Grewal et al. 2004; Du et al. 2009; Khatri-Chhetri et al. 2011; Guo et al. 2015 and Patil et al. 2015) were highly virulent to larvae of many species of white grubs. Therefore, it is expected that EPNs are good candidates for the 
control of L. lepidophora. However, research on the potential of EPNs to suppress L. lepidophora has been limited.

Therefore, the present study aimed to evaluate the efficacy of two EPN species, Steinernema abbasi Elawad and $H$. indica Poinar along with the commonly used chemical insecticide (chlorpyrifos) in an areca nut field infested with $L$. lepidophora.

\section{Methods}

\section{Source of EPNs}

Nematodes, Steinernema abbasi NBAIISa01, and Heterorhabditis indica NBAIIH38, were obtained from the Division of germplasm collection and characterization, National Bureau of Agricultural Insect Resources, Bengaluru, India. Both nematodes were cultured on larvae of the greater wax moth, Galleria mellonella L. (Lepidoptera: Pyralidae) at $25 \pm 1{ }^{\circ} \mathrm{C}$. Infective juveniles (IJs) emerging from the wax moth larvae were collected thrice a week, using White traps. Nematode viability was assessed under a stereomicroscope and considered alive when actively moving or showing response after probing with a needle. EPN suspensions were used for the experiments when more than $98 \%$ of IJs were viable.

\section{Field experiments}

A field experiment was conducted in areca nut plantation, naturally infested with L. lepidophora in the North Canara district, Karnataka $\left(14^{\circ} 78^{\prime} \mathrm{N}, 74^{\circ} 13^{\prime} \mathrm{E}\right.$; $2.88 \mathrm{~m}$ above sea level), India, during the period of August 2015 to October 2017. The experiment was conducted on 22year-old palms planted in sandy clay loam (52-56\% sand, $12-14 \%$ silt, $31-35 \%$ clay, $2 \%$ organic matter, EC $0.21-0.39$, and approximately $17 \%$ moisture). Before the experimentation, natural EPN populations were detected by baiting soil samples with wax moth larvae. No EPN populations were recovered from the experimental field.

The experiment was conducted in a $6912 \mathrm{~m}^{2}$ areca nut field, with a palm spacing of $2.4 \times 2.4 \mathrm{~m}$. The experiment was conducted with a total of 1500 palms per hectare, some palms were not established properly due to the white grubs' infestation. The experiment was organized as a randomized complete block design, with 6 treatments and 15 replicates (blocks), with 10 palms per replicate (a total of 150 palms per treatment). To estimate the larval populations of $L$. lepidophora, five soil samples of $0.3 \times 0.3 \mathrm{~m}$ surface area to a depth of 0 . $3 \mathrm{~m}$, taken at least $0.3 \mathrm{~m}$ distance from palms, were sampled randomly within each block. The number of white grub larvae was determined and the population density of the grub larvae estimated. Pre-application sampling indicated that the site had a resident larval population of L. lepidophora with a density of $2.4 \pm 0$. 40 grubs $\mathrm{m}^{-2}$, and the grubs were mainly in the third larval instar at the time of the experiment.
Soil applications were carried out at 3:00 p.m., light rain, an air temperature of $25{ }^{\circ} \mathrm{C}$, and a soil temperature of $23{ }^{\circ} \mathrm{C}$ at $5 \mathrm{~cm}$ depth. Both S. abbasi and $H$. indica were applied at the concentrations of $1.7 \times 10^{5}$ and $3.5 \times$ $10^{5} \mathrm{IJs}$ palm $^{-1}$ and $3.0 \times 10^{8}$ and $6.0 \times 10^{8} \mathrm{IJs} \mathrm{ha}^{-1}$, respectively. Chlorpyrifos (20\% EC- emulsifiable concentrate) was used as a positive control at a rate of $6 \mathrm{ml} \mathrm{palm}^{-1}$ (equal to $10,000 \mathrm{ml} \mathrm{ha}^{-1}$ ). Water without nematodes or insecticide was used as a negative control. Infective juveniles, in $5 \mathrm{l}$ of water, were poured around the base of each tree and covered $1.2 \mathrm{~m}$ area. A similar volume was used for chlorpyrifos treatment and water control. Watering can and sprinkler can be used to apply the EPNs and insecticides, respectively. Larval populations of the white grub were monitored 2 and 4 weeks after EPNs' application as described before. The effect of treatments on kernel yield was recorded, and estimated the cost of EPNs and chemical insecticide applications were also estimated.

\section{Nematode persistence}

In order to assess the EPNs' persistence in the soil, the mortality of G. mellonella larvae buried in the field was evaluated after 60,90 , and 120 days post-application. To study the nematode persistence, perforated plastic boxes containing four larvae in a mixture of sterilized soil and sand (1:1, moisture 13\%) were buried around the root zone of each palm at a depth of $15 \mathrm{~cm}$. Six days later, they were retrieved and taken back to the laboratory. Live and dead G. mellonella larvae were counted. Dead larvae were incubated in clean Petri dishes with moist filter paper and dissected 3 days later to estimate IJs invasion. There were 15 replicates for each treatment, and the experiment was randomized complete block design. The whole experiment was repeated once with the same number of replicates.

\section{Statistical analysis}

Percentage reduction of the grubs was calculated for each treatment using the equation: $R_{A}(\%)=\left(A_{c}-A_{t}\right) /$ $A_{c} \times 100$, where $R_{A}$ is the percentage reduction of the white grub larvae in the treatment and $A_{c}$ and $A_{t}$ indicate the number of larvae in the control and the treatment, respectively (Liu et al. 2007 and Guo et al. 2013). The cost and benefit of different treatments were estimated based on an IJ application rate of $3.5 \times$ $10^{5} \mathrm{IJ} \mathrm{palm}^{-1}\left(6.0 \times 10^{8} \mathrm{IJ} \mathrm{ha}^{-1}\right)$. Average kernel yield was calculated kilograms per hectare. The cost for the treatments was estimated based on the cost of IJs production on G. mellonella and retail price of the chlorpyrifos on 7 August 2015. Net profit was estimated based on the income of kernels (USD\$ 3.1 per kilogram on 4 October 2017) and the cost per hectare from different treatments. The arcsine 
transformation (\% data) was used for normalization of data before an ANOVA was conducted. Analysis was undertaken on the transformed data, and untransformed means \pm SE are presented. All data were analyzed using PROC GLM (SAS version 9.3; SAS Institute 2011). When ANOVA was significant, comparisons of relevant means were made using Tukey's post-hoc significance test at a significance level $5 \%$.

\section{Results and discussion}

\section{Reduction of white grub larvae}

Results indicated that application of $\mathrm{H}$. indica at 1.7 and $3.5 \times 10^{5} \mathrm{IJs}$ palm $^{-1}$ caused significantly higher percentage of reduction of the grub larvae than other treatments at 3 and 6 weeks after application $(F=70.57$, $\mathrm{df}=4, \quad 126, \quad P<0.0001) \quad($ Fig. 1$)$. Six weeks postapplication, $H$. indica caused $>80 \%$ reduction of the grub larvae, which was significantly higher than the plots treated with $S$. abbasi and chlorpyrifos $(F=70.57, \mathrm{df}=1$, $126, P<0.0001)$. However, treatment with $S$. abbasi was less efficient, and fewer larvae were detected in nematode- and chlorpyrifos-treated plots than that in the water control. These results showed that $H$. indica was more virulent to white grub larvae than $S$. abbasi. Different host-finding strategies exhibited by the "cruiser" $H$. indica (Campbell and Lewis 2002) and "ambusher" $S$. abbasi could explain our findings. H. indica had excellent potential for the control of L. lepidophora as it provided $89 \%$ reduction of $L$. lepidophora larvae, at 6 weeks post application, even at $1.7 \times 10^{5} \mathrm{IJ}$ palm$^{-1}$. These results indicated that such high efficacy, even in the lowest rate of $H$. indica application, may suggest additional grub mortality caused by the $H$. indica progeny emerged from grub larvae infected by the originally applied nematodes.

Six weeks post-applications, percentage reduction of grub larvae was the highest $(89.23 \%)$ by $H$. indica and lowest $(43.21 \%)$ by $S$. abbasi at the rate of $3.5 \times$ $10^{5} \mathrm{IJs}$ palm $^{-1}$, whereas in the plots treated with chlorpyrifos, $60.25 \%$ reduction of the grub larvae was recorded (Fig. 1). Similar results showed that using nematodes could control different white grub species but with various control efficacies, i.e., $S$. scarabaei (100\%), H. bacteriophora (40-50\%), and H. zealandica (73-98\%), against Popillia japonica (Koppenhofer and Fuzy 2003; Grewal et al. 2004; Koppenhofer et al. 2006). Guo et al. (2013 and 2015) reported that S. longicaudum and $H$. bacteriophora application caused >94\% reduction of Holotrachia oblita and S. carpocapsae caused $<20 \%$ reduction in peanut fields. Laznik and Trdan 2015 recorded the lowest efficacy of $H$. bacteriophora, when used for the control of mixed populations of Scarabaeidae species. Therefore, for the effective management of target pests, choosing the appropriate nematode species to be matched with the particular target pest is a paramount importance (Shapiro-Ilan et al. 2012). As the extension of sample time, percentage reductions of $L$. lepidophora significantly increased in the plot treated with $H$. indica, S. abbasi, and chlorpyrifos $(F=23.14, \mathrm{df}=1,266, P<0$.

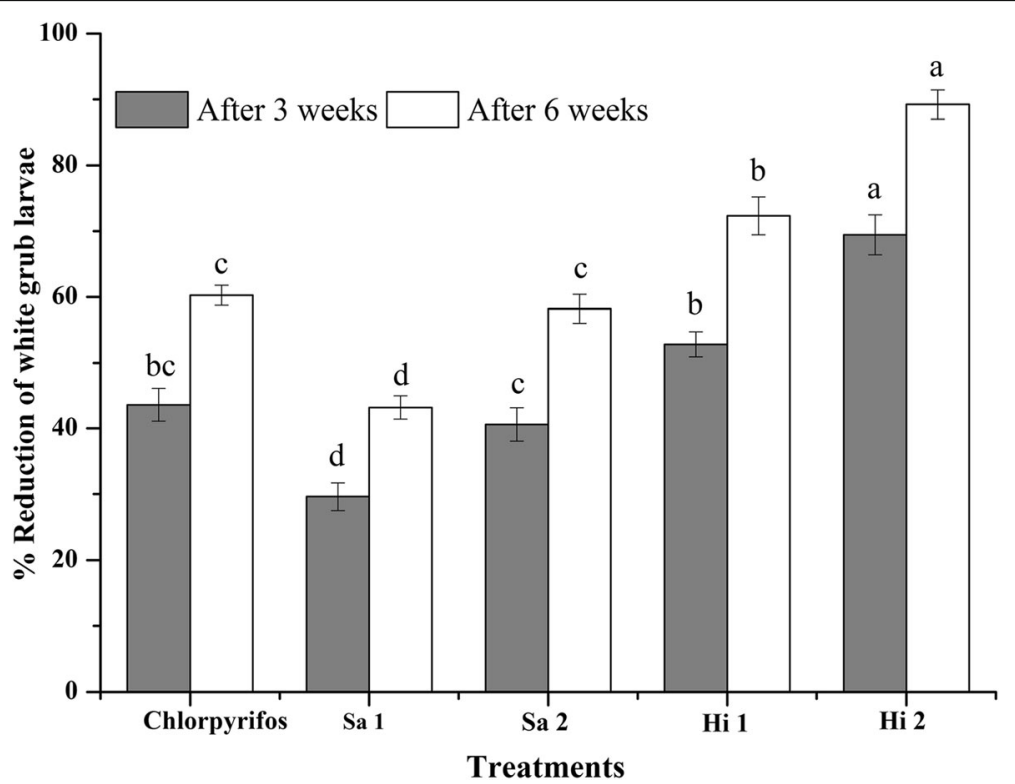

Fig. 1 Cumulative percentage reduction of third-instar larvae of Leucopholis lepidophora in areca nut field with different treatments 3 and 6 weeks after application in North Canara district, Karnataka, India during 2015-2017. Different letters on the top of error bars indicate statistically different values for different nematode concentrations using Tukey's test $(P<0.05)$. Bars = standard error. Sa, Steinernema abbasi; Hi, Heterorhabditis indica;

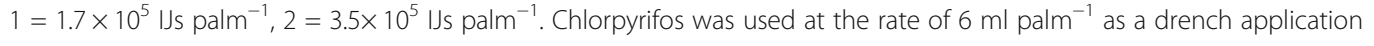


0001) (Fig. 1). S. abbasi at the concentration of $3.5 \times$ $10^{5} \mathrm{IJs}_{\mathrm{s}} \mathrm{palm}^{-1}$ performed at least equally well than the chlorpyrifos treatment, but chlorpyrifos treatment reduced significantly higher percentage of grub larvae than S. abbasi at $1.7 \times 10^{5} \mathrm{IJs} \mathrm{palm}^{-1} . H$. indica was the most efficient in reducing the grub population, followed by the chlorpyrifos and $S$. abbasi treatment.

\section{Nematode persistence}

After the successful establishment in the host, EPNs undergo several cycles of multiplication. The success of this process enhanced their ability to be established in the field. In the present study, because of the successful multiplication of both nematode species, $H$. indica and $S$. abbasi in L. lepidophora larvae, their persistence was recorded in the soil, even 90 days after application. Moreover, the soil moisture of approximately $17 \%$ and temperature of $23{ }^{\circ} \mathrm{C}$ during the control period were favorable for the IJs survival and persistence. Mortality of G. mellonella larvae in nematode-treated soil samples ranged from $28.0 \pm 5.65$ to $37.33 \pm 5.12 \%$, and the differences were insignificant $(P>0.05)$ between treatments at different sample days $(F=0.93, \mathrm{df}=3,162, P \geq 0.4278)$.

\section{Kernel yield of areca nut}

To estimate the areca nut kernel yield, seventy-five palms were selected randomly from each treatment. Ripe nuts were harvested and dried to $8 \%$ moisture. Dried nuts were de-husked, and kernel weight $(\mathrm{kg} / \mathrm{palm})$ of areca nut, i.e., chali (marketable produce), was recorded for computing the yield. Cumulative kernel weights of areca nuts in the plots treated with different treatments during the year are shown in Fig. 2. The kernel yields $(\mathrm{kg} / \mathrm{palm})$ varied significantly among different treatments $(F=200.73 ; \mathrm{df}=5,70 ; P<0.0001)$. The kernel yield harvested from the areca nut plots treated with $H$. indica at $3.5 \times 10^{5} \mathrm{IJs}_{\mathrm{salm}}^{-1}$ was $85.4 \%$ higher than water control and $33.3 \%$ higher than that from chlorpyrifos treatment. That was similar to Guo et al. (2013) who obtained $82.9 \%$ of higher peanut yield in the Holotrachia parallela-infested plots treated with $H$. bacteriophora $\mathrm{H} 06$ at a rate of $1.0 \times 10^{4} \mathrm{IJs}_{\mathrm{j}} \mathrm{plant}^{-1}$ and $30 \%$ higher than that in the chlorpyrifos treatment. Chlorpyrifos-treated palms showed significantly higher yield than $S$. abbasi at $1.7 \times 10^{5}$ IJs palm $^{-1}$, but insignificant difference of the kernel yield was found between the chlorpyrifos and $S$. abbasi at $3.5 \times$ $10^{5} \mathrm{IJs} \mathrm{palm}^{-1}$. Plots treated with chlorpyrifos showed $39 \%$ of increase in kernel yield over control treatment, whereas in plots treated with $S$. abbasi and $H$. indica at $3.5 \times 10^{5} \mathrm{IJs} \mathrm{palm}^{-1}$, the increase rate of kernel yield was 37.27 and $85.4 \%$, respectively.

\section{Cost estimation of the EPN applications}

The wide use of nematodes for the control of the white grubs is still limited because of less availability of nematode products and the high cost. Therefore, in the present study, the cost benefit of the white grub control in areca nut field was estimated (Table 1), where 1500 areca nut palms per hectare were tested. Both nematode

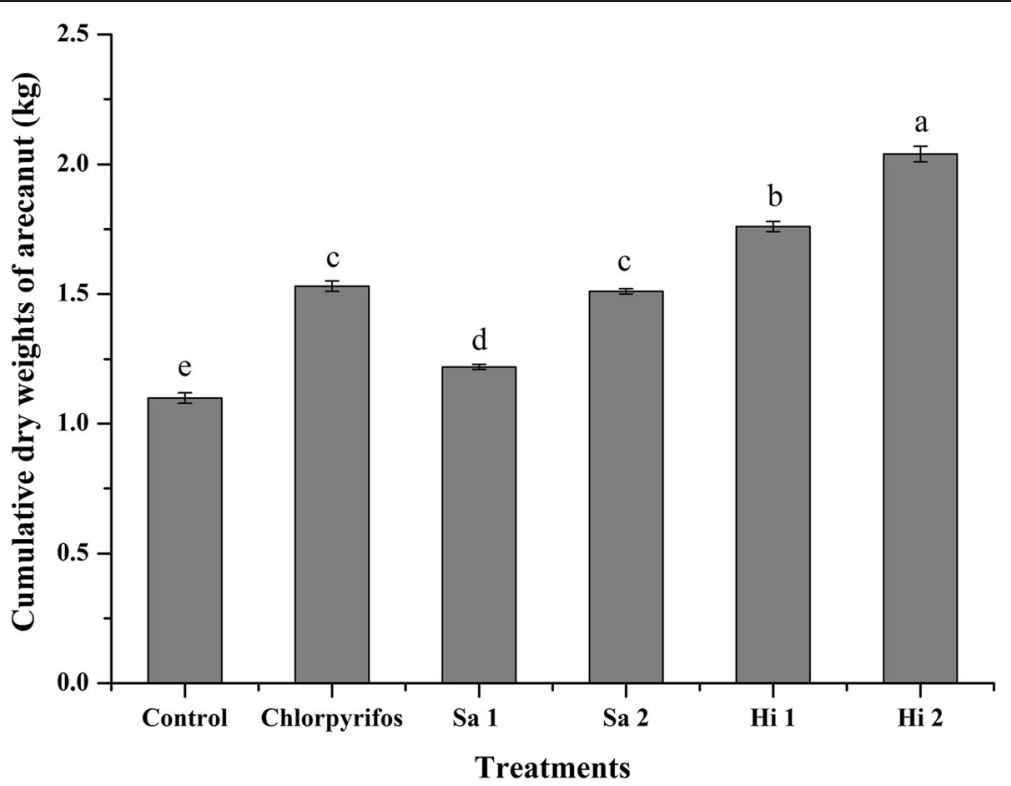

Fig. 2 Cumulative kernel weights of areca nut palms treated with different treatments in North Canara district, Karnataka, India, during 2015-2017. Different letters on the top of error bars indicate statistically different values for different nematode concentrations using Tukey's test $(P<0.05)$. Bars $=s$ tandard error $\mathrm{Sa}$, Steinernema abbasi; Hi, Heterorhabditis indica; $1=1.7 \times 10^{5} \mathrm{Is} \mathrm{palm}^{-1}, 2=3.5 \times 10^{5} \mathrm{IJs} \mathrm{palm}^{-1}$. Chlorpyrifos was used at the rate of $6 \mathrm{ml} \mathrm{palm}^{-1}$ as a drench application 
Table 1 Cost and benefit for the control of third-instar larvae of Leucopholis lepidophora with Heterorhabditis indica, Steinernema abbasi, and chlorpyrifos in the areca nut field

\begin{tabular}{|c|c|c|c|c|c|}
\hline Treatments & Rates ha ${ }^{-1}$ & $\begin{array}{l}\text { Cost of products during 2015-2017 } \\
\left(\text { US\$ ha }{ }^{-1}\right)^{\mathrm{a}}\end{array}$ & $\begin{array}{l}\text { Kernels yield } \\
\left(\mathrm{kg} \mathrm{ha}^{-1}\right)\end{array}$ & $\begin{array}{l}\text { Income of kernels ha }{ }^{-1 c} \\
\text { (US\$) }\end{array}$ & $\begin{array}{l}\text { Net profit } \\
\left(\text { US }^{d} \mathrm{ha}^{-1}\right)\end{array}$ \\
\hline H. indica & $6.0 \times 10^{8} \mathrm{IJs}$ & 370.4 & 1860.0 & 5792.0 & 5421.6 \\
\hline S. abbasi & $6.0 \times 10^{8} \mathrm{IJS}$ & 563.8 & 1140.0 & 3549.0 & 2985.2 \\
\hline Chlorpyrifos & $9000 \mathrm{ml}$ & 68.6 & 1245.0 & 3876.9 & 3808.3 \\
\hline Control & 0 & 0 & 885.0 & 2755.9 & 2755.9 \\
\hline
\end{tabular}

Exchange rate used for conversion to U.S. Dollar: US\$ $1=65.19$ INR (4 October 2017)

${ }^{a}$ Cost for the treatments was estimated based on the cost of IJs production on wax moth larvae and retail price of the chlorpyrifos in 7 August 2015

${ }^{\mathrm{b} C}$ Cumulative kernel yield during 2015-2017

'Local purchase price of the processed kernels (Chali) was (US\$3.1/kg) on 4 October 2017

${ }^{d}$ Net profit was estimated only based on the income of kernels and the cost per hectare from different treatments

species were used at the rate of $6.0 \times 10^{8} \mathrm{IJs} \mathrm{ha}^{-1}$. The average profits estimated, based on the price of the kernel (chali) and the cost per hectare for different treatments, were in the order of water control $<S$. abbasi < chlorpyrifos $<$ H. indica.

Georgis et al. (2006) estimated the cost involved in control of $P$. japonica in the USA using in vitro cultured heterorhabditis products as higher than US\$ $500 \mathrm{ha}^{-1}$, which was four times as much as similarly effective organophosphate and carbamate insecticides and twice as much as the preventatives imidacloprid, clothianidin, and halofenozide control. Similarly, Laznik et al. (2010) reported that even after efficient control of Leptinotarsa decemlineata Say, using S. feltiae isolate B30 Laznik and the commercial products of S. feltiae (Entonem) in potato cultivation in Slovenia, broader implementation of these nematode strains in potato cultivation was difficult because of their high price. In the present study, although the cost for $H$. indica (US\$ $370.4 \mathrm{ha}^{-1}$ ) at a rate of $6.0 \times 10^{8} \mathrm{IJs} \mathrm{ha}^{-1}$ is almost five times as much as chlorpyrifos (US\$ $68.6 \mathrm{ha}^{-1}$ ) , but control efficacy, profit, and safety concerns encourage the use of $H$. indica for the management of areca nut white grubs. Therefore, management of the white grubs by using $H$. indica in areca nut fields in India has good prospects.

\section{Conclusions}

The present study showed the potential of $H$. indica for the control of L. lepidophora grubs in the areca nut field. More studies are needed on the control efficacy of the combined applications of nematode species and chemical insecticides that will increase the efficacy of the EPNs to bring down their cost.

\section{Acknowledgements}

The authors are grateful to the Indian Council of Agricultural Research, New Delhi, India, and the Director, ICAR-National Bureau of Agricultural Insect Resources, Bengaluru, India, for the facilities provided for conducting the study.

\section{Funding}

This research work was financially supported by the Science and Engineering Research Board (SERB) of the Department of Science and Technology (DST), Government of India under Start-Up Research Grant for Young Scientists (\# SB/YS/LS-28/2013) to the first author.
Availability of data and materials

All data are available at the end of the article and the materials used in this work are of high quality and grade.

\section{Authors' contributions}

JP designed the research. JP and VR conducted the experiments. JP analyzed the data and wrote the manuscript. JP obtained the funding. Both authors read and approved the final manuscript.

\section{Ethics approval and consent to participate}

All experimental works were approved by Science and Engineering Research Board (SERB) of the Department of Science and Technology (DST),

Government of India and ICAR-National Bureau of Agricultural Insect Resources, Bengaluru, India.

\section{Competing interests}

The authors declare that they have no competing interests.

\section{Publisher's Note}

Springer Nature remains neutral with regard to jurisdictional claims in published maps and institutional affiliations.

Received: 27 February 2018 Accepted: 17 April 2018

Published online: 03 May 2018

\section{References}

Adsule VM, Patil SM (1994) Biology of sugarcane white grub, Leucopholis lepidophora Blanchard Coleoptera: Scarabaeidae: Melolonthinae. Indian Sugar 44:25-28

Campbell JF and Lewis EE (2002). Entomopathogenic nematode host search strategies. In: Lewis EE, Campbell JF, Sukhdeo MVK (eds) The behavioural ecology of parasites. 1st ed. CABI International, Wallingford, UK, pp. 13-38

Du X, Liu Q, Zhang L, Liang L, Xie N, Zhang S (2009) Application technology of Steinernema longicaudum BPS strain in peanut fields for chafer grub control. Agrochemicals 48:379-388

Georgis R, Koppenhofer AM, Lacey LA, Belair G, Duncan LW, Grewal PS, Samish M, Tan L, Torr P, van Tol RWHM (2006) Successes and failures in the use of parasitic nematodes for pest control. Biol Control 38:103-123

Grewal PS, Koppenhofer AM and Choo HY (2005). Lawn, turfgrass and pasture applications. In: Grewal PS, Ehlers RU, Shapiro-llan DI (eds) Nematodes as biocontrol agents. 1st ed. CABI International, Wallingford. pp. 115-146

Grewal PS, Power KT, Grewal SK, Suggars A, Haupricht S (2004) Enhanced consistency in biological control of white grubs (Coleoptera: Scarabaeidae) with new strains of entomopathogenic nematodes. Biol Control 30:73-82

Guo W, Yan X, Zhao G, Chen J, Han R (2015) Efficacy of entomopathogenic Steinernema and Heterorhabditis nematodes against Holotrichia oblita. J Pest Sci 88:359-368

Guo WX, Yan X, Zhao GY, Han RC (2013) Efficacy of entomopathogenic Steinernema and Heterorhabditis nematodes against white grubs (Coleoptera: Scarabaeidae) in peanut fields. J Econ Entomol 106:1112-1117

Kalleshwaraswamy CM, Adarsha SK, Naveena NL, Sharanabasappa (2015) Incidence of arecanut white grubs (Leucopholis spp.) in hilly and coastal regions of Karnataka, India. Current Biotica 8:423-424 
Kaya HK, Gaugler R (1993) Entomopathogenic nematodes. Annu Rev Entomol 38: $181-206$

Khatri-Chhetri HB, Timsina GP, Manandhar HK, Moens M (2011) Potential of Nepalese entomopathogenic nematodes as biocontrol agents against Holotrichia longipennis Blanch. (Coleoptera: Scarabaeidae). J Pest Sci 84:457-469

Koppenhofer AM, Brown IM, Gaugler R, Grewal PS, Kaya HK, Klein MG (2000) Synergism of entomopathogenic nematodes and imidacloprid against white grubs: greenhouse and field evaluation. Biol Control 19:245-252

Koppenhofer AM, Fuzy EM (2003) Steinernema scarabaei for the control of white grubs. Biol Control 28:47-59

Koppenhofer AM, Grewal PS, Fuzy EM (2006) Virulence of the entomopathogenic nematodes Heterorhabditis bacteriophora, H. zealandica, and Steinernema scarabaei against five white grub species (Coleoptera: Scarabaeidae) of economic importance in turfgrass in North America. Biol Control 38:397-404 Laznik Z, Toth T, Lakatos T, Vidrih M, Trdan S (2010) Control of the Colorado potato beetle (Leptinotarsa decemlineata [Say]) on potato under field conditions: a comparison of the efficacy of foliar application of two strains of Steinernema feltiae (Filipjev) and spraying with thiametoxam. J Plant Dis Prot 117:129-135

Laznik Z, Trdan S (2015) Failure of entomopathogens to control white grubs (Coleoptera: Scarabaeidae). Acta Agric Scand Sect B Soil Plant Sci 65:95-108

Liu Q, Li J, Xu X, Sun C, Kang Y, Zhou H, Hu D, Ma J, Li S (2007). The preliminary study on grub control with Rhabditis (Oscheius) spp. in peanut fields. Acta Bot Boreal-Occident Sin 22:250-253.

Patil J, Rajkumar, Subhaharan K (2015) Synergism of entomopathogenic nematode and Imidacloprid: a curative tool to coconut white grub, Leucopholis coniophora (Coloeptera: Melolonthinae). Vegetos 28:184-190

Ranga Rao GV and Rameshwar Rao V (2013). Groundnut insect pests identification and management. In: Handbook on groundnut insect pests identification and management. Information Bulletin No. 39, ICRISAT, Andhra Pradesh. pp. 88

SAS Institute (2011). SAS version 9.3 system options: reference, 2nd edition. SAS Institute, Cary

Shapiro-llan DI, Han RC, Dolinksi C (2012) Entomopathogenic nematode production and application technology. J Nematol 44:206-217

Toepfer S, Kurtz B, Kuhlmann U (2010) Influence of soil on the efficacy of entomopathogenic nematodes in reducing Diabrotica virgifera virgifera in maize. J Pest Sci 83:257-264

Veeresh GK (1983). White grubs. In: Veeresh, GK, Rajagopal D, editors. Applied Soil Biology and Ecology. 1st ed. Oxford and IBH Publishing, New Delhi, pp. 413.

Yan X, Moens M, Han RC, Chen SL, De Clercq P (2012) Effects of selected insecticides on osmotically treated entomopathogenic nematodes. J Plant Dis Protect 119:152-158

\section{Submit your manuscript to a SpringerOpen ${ }^{\circ}$ journal and benefit from:}

- Convenient online submission

- Rigorous peer review

- Open access: articles freely available online

- High visibility within the field

- Retaining the copyright to your article

Submit your next manuscript at $>$ springeropen.com 